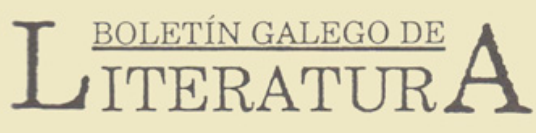

Boletín Galego de Literatura, (59), 2021. ISSN-e: 2174-4025

https://doi.org/10.15304/bgl.59.7715

Estudos

\title{
Textos-moldura como literatura: o meta-paratexto de um quebra-cabeça literário
}

Frame-texts as literature: the meta-paratext of a literary puzzle

Carlos Gontijo Rosa

Pontifícia Universidade Católica de São Paulo (PUC-SP) / FAPESP, Brasil

carlosgontijo@gmail.com

Recibido: 16/05/2021; Aceptado: 13/10/2021

\section{Resumo}

Neste artigo, propomo-nos a reflexão do "quebra-cabeça literário" intitulado $S$., escrito por J. J. Abrams e Doug Dorst, publicado nos EUA em 2013 e no Brasil em 2015. A obra literária estrutura sua narrativa metaficcionalmente, o que quer dizer que tudo o que explicarmos faz parte da ficção construída pelos autores empíricos. A base para o quebra-cabeças é o romance $O$ navio de Teseu, escrito por V. M. Straka e editado por F. X. Caldeira, que também escreve a "Nota de tradução e prefácio". Sobre ("acerca de" e "em cima de") a obra, dois leitores dialogam, comentando a publicação, o autor, o editor e a si próprios. É dessa sobreposição de vozes que extraímos nossa reflexão acerca da obra, no sentido de rastrear visões teórico-críticas presentes nos elementos meta-paratextuais de $O$ navio de Teseu, cujas autorias ficcionais pertencem às personagens Caldeira, no prefácio e nas notas de rodapé, e Jennifer e Eric, nas marginálias. Há uma tensão entre os críticos-leitores da obra de Straka que será explorada para identificar uma narrativa secundária de ordem metaliterária. Ao final, busca-se evidenciar como a materialidade gráfica do livro-objeto interfere e constrói, ela própria, uma narrativa a mais em $S$.

Palavras-chave: metaficção; narrativa em abismo; marginália; paratexto; livro-objeto.

\begin{abstract}
In this paper, we reflect upon the "literary puzzle" named $S$., written by J. J. Abrams and Doug Dorst, published in the USA in 2013 and in Brazil in 2015. The literary work structures its narrative metafictionally, which means everything we explain here is part of the fiction constructed by the empirical authors. The basis for the puzzle is the novel The Ship of Theseus, written by V. M. Straka and edited by F. X. Caldeira, who also writes the "Foreword and Translation Note". Two readers have a debate over the work (about it and literally above it), with comments on the publication, the author, the editor, and themselves. It is from this juxtaposition of voices that we extract our reflections about the work, following the trails of the criticaltheoretical voices identifiable within the meta-paratextual elements of The Ship of Theseus. The fictional authors of these paratexts are the characters Caldeira, in the foreword and footnotes, and Jennifer and Eric, along the book's marginalia. There is a tension between the two critics-readers of Straka's work, which will be explored in order to identify a metaliterary secondary narrative. In the end, we seek to highlight how the graphic materiality of the book-object contributes to and actually builds up an extra narrative within $S$.
\end{abstract}


Keywords: metafiction; mise en abyme; marginalia; paratext; object-book.

O prólogo, quando os astros são favoráveis, não é uma forma subalterna do brinde; é uma espécie lateral da crítica.

Jorge Luís Borges

A expressão "quebra-cabeça literário" surge de um anônimo autor de notícias do blog da Editora Intrínseca, cujo texto, "O quebra-cabeça literário de J.J. Abrams" (Intrínseca, 2015), foi publicado em novembro de 2015, na iminência do lançamento de $S$. no Brasil (dezembro de 2015).

$S$. é o nome desse quebra-cabeças literário que agrupa tudo o que consta dentro do box no qual vem o livro. Ele é composto pelo romance $O$ navio de Teseu, escrito pelo autor fictício V. M. Straka, e pelos muitos paratextos que o emolduram, todos eles ficcionais: o prefácio e as notas de F. X. Caldeira e a narrativa paralela de Eric, doutorando que estuda Straka, e Jen, que cursa o último ano de graduação em Literatura. A história de Jen e Eric, que é narrada "à mão" às margens do livro e se mistura com anotações e pesquisas de ambos sobre o livro e seu autor, é apresentada de forma não linear, com alguma marcação de "antes" e "depois" possível de ser percebida pela cor da caneta utilizada -em determinado momento, em que estão juntos, mas ainda escrevendo no livro, a tinta se torna da mesma cor ${ }^{1}$.

Figura 1. Exemplo de página anotada pelas personagens. Eric escreve em letra de forma e Jen, em letra cursiva.Percebe-se nela três diferentes cores utilizadas por Jen e quatro, por Eric

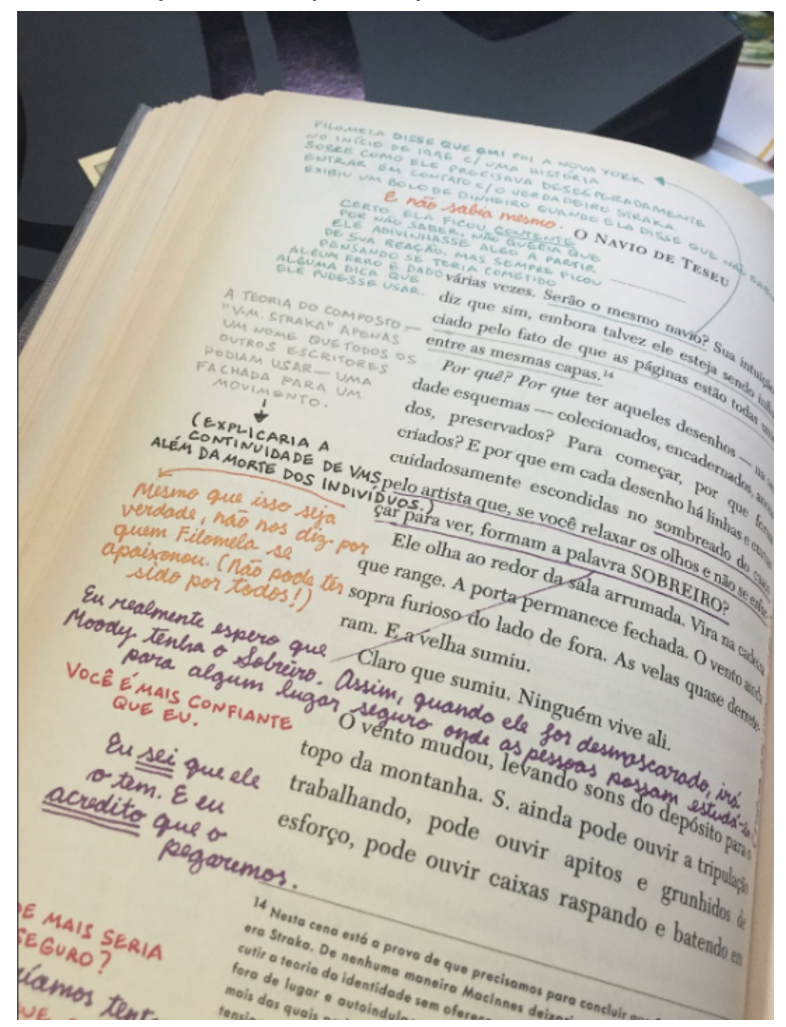

Imagem de divulgação disponível em: https://www.amazon.com.br/S-J-Abrams/dp/8580575567 (consulta: 22 julho, 2021). 
Além disso, há muitos objetos manipuláveis no meio do livro. Como diz o idealizador do projeto, J.J. Abrams, em entrevista ao The New Yorker (Rothman, 2013):

Na era do e-mail e das mensagens instantâneas, quando tudo é enviado para a nuvem e torna-se intangível, $S$. é intencionalmente tangível. Queríamos incluir coisas que você pode segurar nas mãos: cartões-postais, fotocópias, documentos jurídicos, páginas de jornais, um mapa desenhado em um guardanapo. ${ }^{2}$

Figura 2. Box com livro O navío de Teseu. Todos os objetos espalhados encontram-se dentro do livro e fazem parte da narrativa

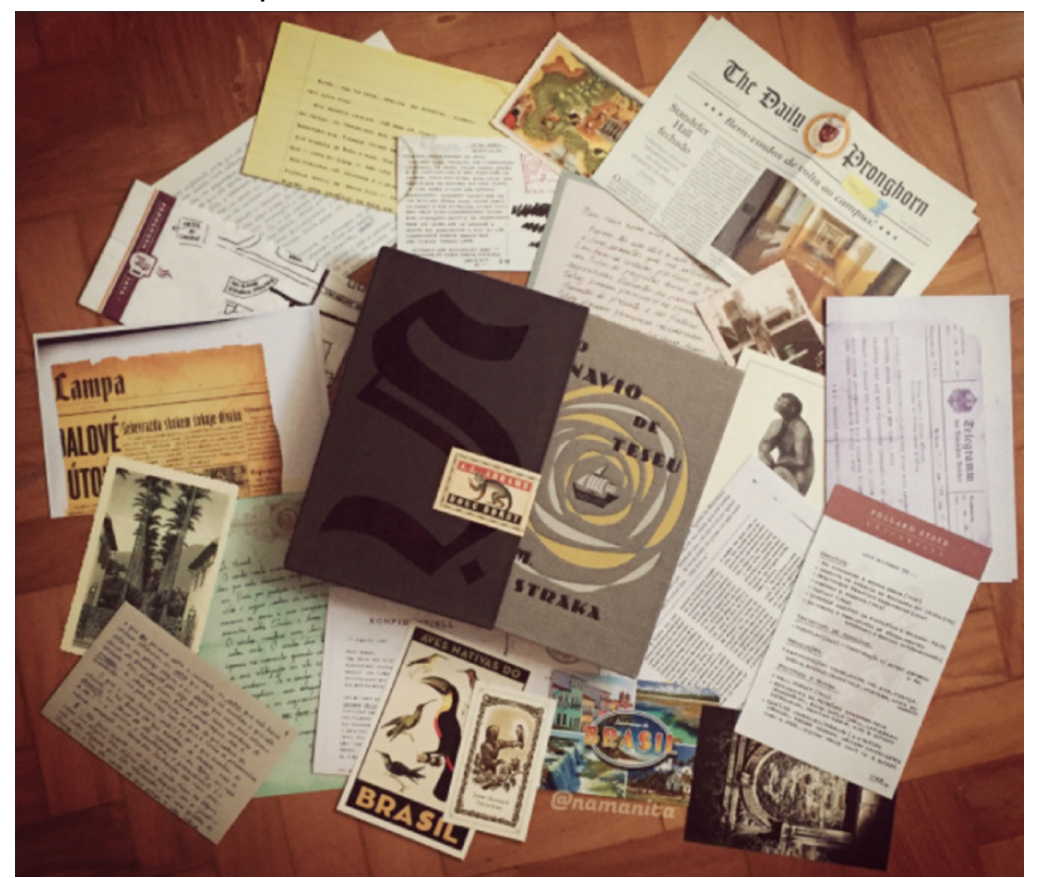

Imagem disponível em: https://alemdolivro.com/2016/01/14/s-j-j-abrams-e-doug-dorst/ (consulta: 22 julho, 2021).

A distinção das vozes discursivas, portanto, é dada a partir da materialidade gráfica da publicação -havendo, inclusive, outras vozes menores, como bilhetes com a letra das personagens F. X. Caldeira e do pesquisador francês Desjardins.

Designer e sócia da editora paulistana Ubu, Elaine Ramos explica que o texto e o livro podem estabelecer diálogo em várias camadas, seja na escolha de uma tipografia, gerando a forma visual do conteúdo textual, ou se expandindo para a estrutura do livro, propondo uma interação menos convencional "entre o conteúdo e o leitor, num projeto mais experimental", aponta. (Maia, 2019, s/p.)

Percebemos, portanto, que a manipulação da materialidade do objeto literário é essencial para a leitura de $S$. Tal perspectiva de leitura confronta aquilo que Bakhtin (2014, p. 19, grifo do autor) afirma:

pode-se dizer que a estética material, como hipótese de trabalho, é inócua e, numa conscientização clara e metódica dos limites do seu emprego, pode até tornar-se fecunda, se for estudada apenas a técnica da obra de arte, mas tornar-se-á evidentemente prejudicial e inaceitável quando, baseado nela, se tentar compreender e estudar a obra de arte como um todo, na sua singularidade e significação estéticas.

Bakhtin escreve em 1924, quando certamente a questão da materialidade do objeto literário era tratada de maneira bastante distinta. Aqui, portanto, propomos uma ampliação do pensamento 
bakhtiniano, pois o objeto estético analisado extrapola os limites da literatura olhada por Bakhtin. A proposta de J.J. Abrams e Doug Dorst com a produção desse livro-objeto é justamente imiscuir as questões materiais e de conteúdo da obra de arte literária. Entretanto, se nos ativermos apenas às questões materiais, não alcançaremos o todo da análise estética a ser empreendida sobre esse objeto literário:

Se, durante um longo período, a História do livro assentava, essencialmente, na sua dimensão textual (no seu conteúdo), nos últimos tempos, têm sido especialmente valorizadas a sua condição material, a sua forma, a sua anatomia (Pelachaud, 2010, p. 430), idealmente ao serviço do conteúdo. (Martins e Silva, 2020, p. 101, grifo nosso)

Assim, por estar "ao serviço do conteúdo", a materialidade do livro-objeto não ganha protagonismo "solo" na criação literária, mas sempre, como preconiza Bakhtin (2014, p. 22, grifo no original), atrelada ao conteúdo, pois "é o conteúdo da atividade estética (contemplação) orientada sobre a obra que constitui o objeto da análise estética".

Corroborando a perspectiva de J.J. Abrams acerca de $S$. enquanto livro-objeto, os editores Paulo Verano e Angela Mendes afirmam que "o livro-objeto é, portanto, para nós o livro que se torna importante por sua materialidade. Que faz sentido como objeto, pegando na mão; em que a leitura se amplia a partir daí" (Quindim, 2020, s/p.). 0 que também pode ser entendido a partir de um ponto de vista mais sensorial, que valoriza a recepção do leitor, como destaca Maia (2019, s/p.):

o códice pode ser não só palco da experiência afetiva do texto que você curiosamente resolveu ler até o momento, mas também uma forma de vivência poética. Assim, o livro transcende o suporte para se constituir no corpo do que você lê e sente.

"O livro-objeto constrói narrativas novas e também reinventa o planejado, permitindo nuances novas" (Quindim, 2020). Assim, ainda seguindo Bakhtin (2014, p. 22, grifo no original), afirmamos que iremos "compreender a obra exterior, material, como um objeto artístico a ser realizado, como aparato técnico da realização estética". É, portanto, do "caos organizado" de $S$., dessa sobreposição de vozes concretamente construídas no livro enquanto objeto, que extraímos nossa reflexão acerca da obra, no sentido de rastrear visões teórico-críticas presentes nos elementos meta-paratextuais.

E por que "meta-paratextuais"? O livro constitui uma espécie de narrativa em abismo (miseen abyme $)^{3}$, mas que se volta sobre si mesma, uma vez que -e isso é o enredo principal da narrativao estudo de $O$ navio de Teseu leva Jen e Eric a se conhecerem e se aproximarem à medida que vão desvendando as mensagens ocultas presentes no volume: sua história de amor vai se desenrolando à medida que descobrem o amor entre Straka e Caldeira ${ }^{4}$; ou suas vidas são colocadas em risco à medida que descobrem a existência de sociedades secretas que regem as conspirações políticas contadas por Straka. Esta narrativa em abismo é calcada principalmente na forma/conteúdo do livro. Mas há uma narrativa em abismo também na forma/materialidade: um autor comentado por uma tradutora/editora/crítica, comentada por Eric jovem, comentado por Eric/Jen adultos, comentados por si mesmos no futuro ${ }^{5}$ : 
Figura 3. imagem da página 70 do livro

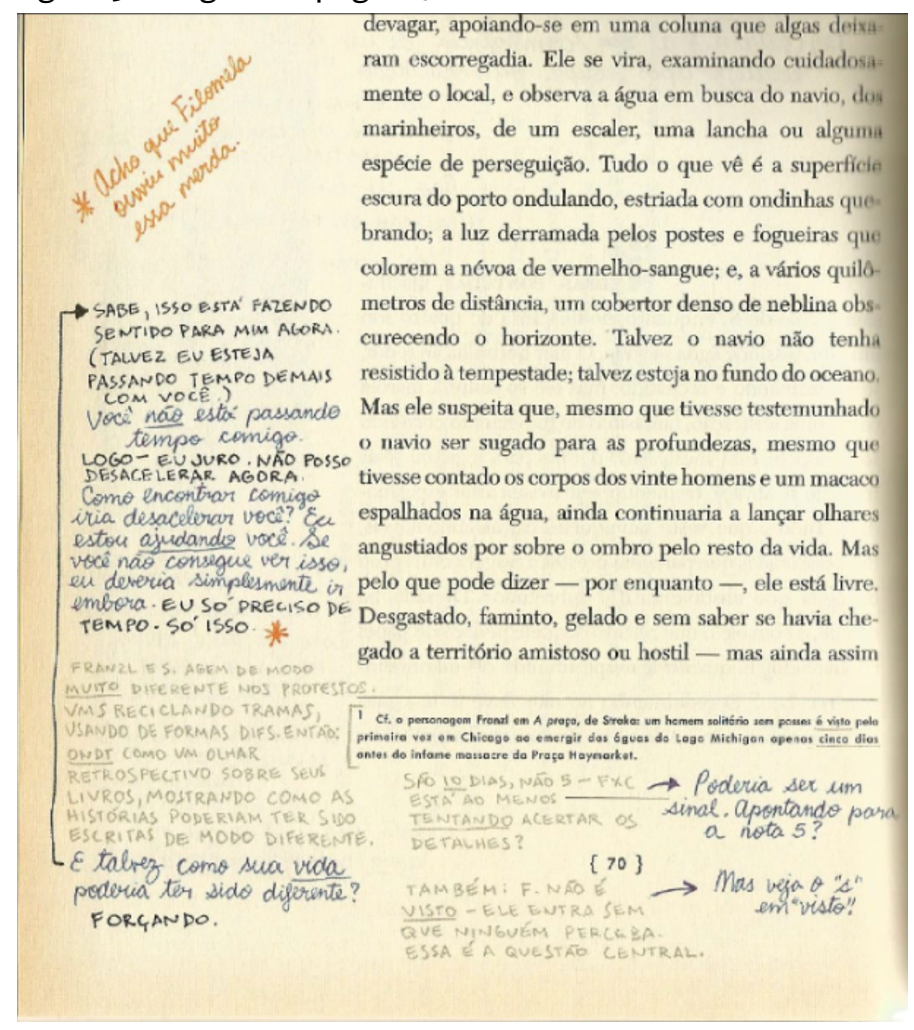

Assim, "a mise en abyme denuncia uma dimensão reflexiva do discurso, uma consciência estética activa ponderando a ficção, em geral, ou um aspecto dela, em particular, e evidenciando-a através de uma redundância textual que reforça a coerência e, com ela, a previsibilidade ficcionais" (Rita, 2010, s/p.). Os autores vão lançar mão desses ecos entre as intrigas da narrativa para entrelaçar e desenvolver cada uma das histórias.

Quanto à ligação entre as intrigas principal e secundárias, Diego Marín (1958, p. 21), embora falasse do Século de Ouro espanhol, poderia perfeitamente estar falando da edição de $S$. quando afirma que há "maior prazer estético em alcançar a unidade e ordem através da multiplicidade e da aparente desordem que por meio da simplicidade e clareza das obras clássicas" ${ }^{6} .0$ autor ainda propõe uma tipologia acerca dos tipos de contato possíveis entre as intrigas principal e secundárias, perante a qual primeiro é necessário estabelecer qual seria a intriga central e quais orbitariam em torno dela.

Em $S$., a intriga principal claramente é a narrativa $O$ navio de Teseu, identificada não apenas materialmente, mas também em relação ao seu conteúdo, que funciona como motivador dos comentários prefacial e em notações e dos diálogos e das pesquisas acerca das condições de produção do livro e dos dados biográficos do autor e seu grupo ${ }^{7}$.

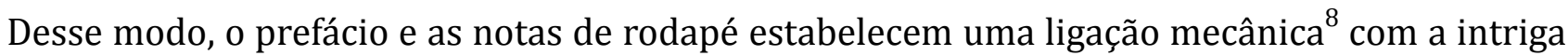
principal, pois está subordinada e intrinsecamente relacionada a ela -mesmo quando nossas chaves de leitura mudam com as novas interpretações trazidas pelos leitores-personagens da grande narrativa, as notas de Caldeira só podem ser lidas a partir dos trechos a que elas se referem. 
Já as demais histórias (intrigas) completamente desenvolvidas à margem tendem a estabelecer outros tipos de ligação com a intriga principal -ou até entre si mesmas.

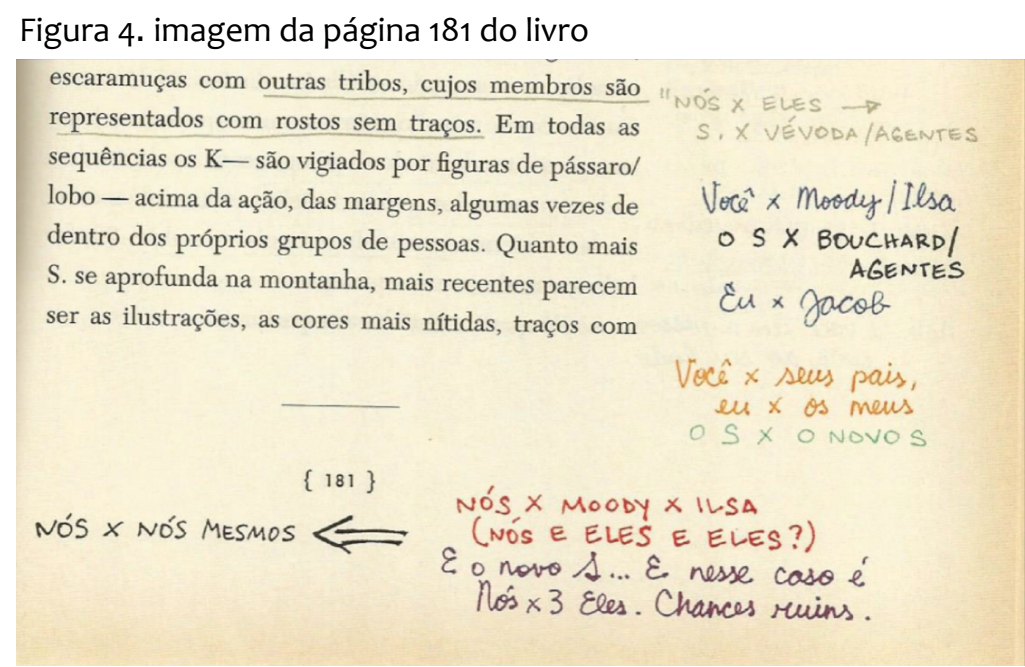

Há uma ligação formal quando o próprio leitor precisa estabelecer as relações de paralelismo ou contraste entre as intrigas, como é o caso das histórias pessoais de Eric e Jen. No caso, Eric tem um embate com seu ex-orientador (Moody) e sua antiga colega de trabalho (Ilsa), embate que inclusive o impede de circular pelo campus e o faz andar por dutos subterrâneos. Já Jen tem os conflitos usuais de uma graduanda em vias de se formar inerentes à aprovação nas últimas disciplinas do curso e seu futuro profissional, além de embates familiares, cuja ligação contrasta com todas as demais personagens do quebra-cabeça literário -nenhuma delas tem qualquer ligação familiar, além de Jen.

Também se pode perceber uma ligação temática por paralelismo entre as histórias amorosas de Eric e Jen e aquela que eles vão descobrindo que houve entre Straka e Caldeira -já exibida em excerto acima. Entretanto, a ligação entre as histórias passa do paralelismo ao contraste quando Eric e Jen se encontram e, ao final, ficam juntos: 
ada de um barril marcado ;ionante mistura dos vinhos eos, o maior exemplo de sua de se permitir uma dose de ¡o está simplesmente dizendo congelado, franze o rosto ar a morte.

ergunta aos convidados, mas a murmura: - Pássaros. Tem em minhas adegas.
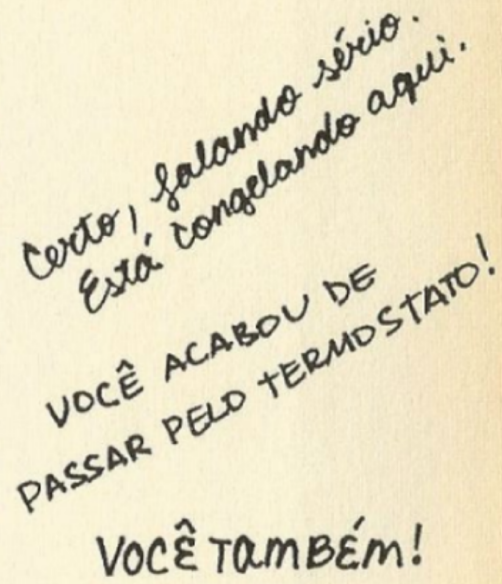

Chame novamente.
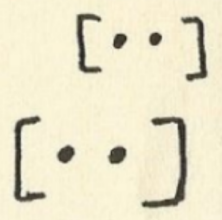

[**]: "Este é o som dos meus olhos revirando" (p. iii, folha de rostro).

Figura 6. detalhe da margem da página 454 do livro

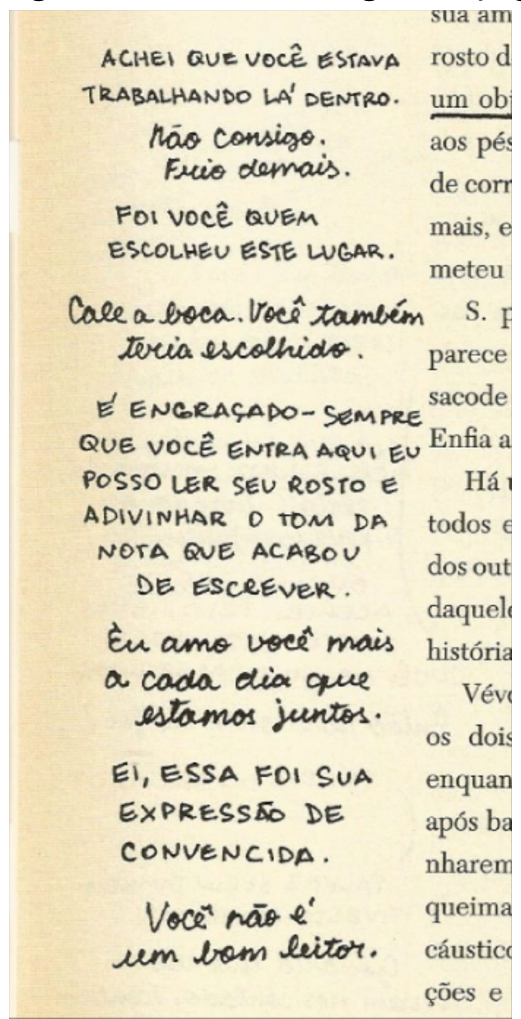


Note-se que todas as intercorrências ${ }^{9}$ que apontam uma convivência entre Jen e Eric no mesmo espaço estão no último capítulo do livro (Capítulo 10), pois, embora essa narrativa marginal não tenha uma sequência temporal linear, ela ainda mantém certo suspense, que só é resolvido no capítulo resolutivo da narrativa de $O$ navio de Teseu, numa ligação formal entre as intrigas.

Há uma grande ligação formal paralelística entre as intrigas quando, na narrativa de $O$ navio de Teseu, o protagonista $S^{10}{ }^{10}$ é perseguido por um grupo de cujos propósitos age em contrário. Assim também Straka foi perseguido por grandes corporações e governos corruptos que denunciava em seus livros e Eric é perseguido pelo seu ex-orientador, Moody, cujas descobertas de Eric sobre Straka tenta (e às vezes consegue) atribuir a si. S., Straka e Eric precisam se manter à sombra, esgueirando-se seja pelos espaços narrativos do livro, pelo mundo ou pelos subterrâneos do campus, respectivamente, para que consigam realizar cada qual o seu trabalho sem a intervenção negativa de seus opositores. S., Eric e Straka, bem como Jen e Filomela, são escritos de maneira a cativar o leitor. Estabelece-se, então, uma dicotomia entre bem e mal que faz com que acompanhemos e torçamos para cada um deles.

Por fim, as notas de rodapé, em todos os momentos, estabelecem relação mecânica com a intriga principal, como já dito. Entretanto, quando Jen e Eric começam a aprofundar em seus sentidos, elas ganham autonomia narrativa e carregam em si códigos que se ligam à narrativa externa ao romance, relativa à perseguição de Straka e do S. pelo Novo S:

$\left\{{ }^{11}\right.$ Sei que as notas de rodapé são realmente estranhas -mas e se elas não forem informativas? E se forem sinais ou mensagens para alguém -como o próprio Straka?\} (p. ii)

\{A Roda de Eötvös ${ }^{12}$ é a chave para decodificar os enigmas em Coriolis, certo? Talvez funcionasse aqui, se essas notas estiverem em código?\} (p. 3)

Obviamente, as vozes das personagens, mesmo aquelas externas a $O$ navio de Teseu, como Caldeira, Jen e Eric, ainda não são "vozes do mundo real", autorais, externas à narrativa. 0 prefixo "meta-" tem o sentido de uma reflexão sobre si. Ao ligá-lo a "paratexto", queremos dizer que vamos analisar, em $S$., a reflexão que os paratextos fazem sobre si mesmos na narrativa -como no caso do excerto acima (e muitos outros) em que as anotações de Jen e Eric comentam as notas de Caldeira ou escritos anteriores feitos por eles mesmos.

No site da Porto Editora (s/d., s/p.) lemos que "o paratexto serve para orientar o leitor, a fim de motivar para a leitura da obra ou realçar determinados aspetos". De maneira geral, Genette (2006, p. 9-10) define os elementos constitutivos do paratexto como

título, subtítulo, intertítulos, prefácios, posfácios, advertências, prólogos, etc.; notas marginais, de rodapé, de fim de texto; epígrafes; ilustrações; errata, orelha, capa, e tantos outros tipos de sinais acessórios, autógrafos ou alógrafos, que fornecem ao texto um aparato (variável) e por vezes um comentário, oficial ou oficioso, do qual o leitor, o mais purista e o menos vocacionado à erudição externa, nem sempre pode dispor tão facilmente como desejaria e pretende.

Assim, tudo o que é enunciado pelas personagens Caldeira, Eric e Jen corresponde a algum tipo de paratexto, pois tudo gira em torno do texto-base de Straka:

Na perspectiva paratextual, o texto é ampliado pelos elementos-fronteira que o envolve[m], como os elementos pré-textuais e pós-textuais, mas também pela rede de comentários, próprios da crítica ou fora do âmbito dela. Assim, percebendo-se uma relação interdiscursiva, chega-se ao hipertexto. Com esse intuito, o prolongamento da obra, a partir de seus invólucros, tem as funções de apresentar e presentificar, torná-la presente, assegurando sua recepção. (Araujo, 2010, p. 2) 
Uma vez que a função do paratexto pode ir de comunicar uma simples informação até a exposição de uma intenção ou uma interpretação do texto-base, os autores de $S$. o utilizam como instrumento para a construção da narrativa, numa retroalimentação entre texto e paratexto -que, na situação, se torna, também ele, texto.

Como há, nos paratextos de $S$., uma multiplicidade de sentidos e narrativas se entrecruzando (Idris, 2016), centraremos nossa discussão na "Nota de tradução e prefácio" (p. v-vix), escrita por F. X. Caldeira e comentada por Jen e Eric em diferentes momentos de sua linha temporal.

Como já dito, além desse texto, são de Caldeira as notas de rodapé de todo o volume. Interessa ver que Genette, já no início do seu Paratextos editoriais (2009, p. 11, grifo no original), agrupa os dois elementos paratextuais numa mesma frase: "ninguém é obrigado a ler um prefácio, mesmo que essa liberdade nem sempre seja bem-vinda para o autor, e veremos que muitas notas são dirigidas apenas a certos leitores". 0 jogo dos autores de $S$. já começa aí, pois o livro-objeto que o leitor tem em mãos pressupõe a apreciação dele integralmente, desde o rompimento do lacre que sela o box em que o livro é vendido e tudo o que nele é contido até o final da leitura.

Sobre o prefácio -no sentido de suspensão de sua condição "não obrigatória"13 ou, como diz Borges (2009, p. 8), "uma espécie lateral de crítica"-, os autores jogam com seu leitor, trazendoo para o centro da narrativa. Já nas notas de rodapé a subversão é inversa, pois elas fingem ser geral, mas são dirigidas a um leitor específico: V. M. Straka, o autor do livro (que provavelmente está morto, como é apresentado no próprio prefácio). Caldeira tenta se comunicar com ele através das notas e de pequenas alterações no que seriam os originais do romance $O$ navio de Teseu. Mas Genette (2009), nossa referência para a questão formal dos paratextos, se furta a tratar de "notas ficcionais", limitando-se a notas emitidas por autores-criadores de carne e osso, a partir de sua enunciação no mundo real, ou seja, um olhar de fora da narrativa sobre ela. E nem sobre essas lança um olhar lisonjeiro, pois as vê como um “'gênero' cujas manifestações são, por definição, pontuais, fragmentadas, como que pulverulentas, para não dizer poeirentas” (Genette, 2009, p. 281).

As notas de Caldeira, entretanto, ficcionalmente mimetizam (ou emulam) uma nota "real", tecendo comentários históricos, geográficos, políticos, sociais ou biográficos sobre V. M. Straka e seu entorno. Vejamos como o autor francês define este elemento paratextual que pode nos ser válido para a análise:

Uma nota é um enunciado de tamanho variável (basta uma palavra) relativo a um segmento mais ou menos determinado de um texto, e disposto seja em frente seja como referência a esse segmento. [...] em muitos casos, o discurso do prefácio e o do aparato de notas estão numa relação muito estreita de continuidade e de homogeneidade. (Genette, 2009, p. 281-282)

Vemos que tanto as notas como as anotações marginais de Jen e Eric frequentemente estão ligadas, mesmo que como "início de conversa", a alguma passagem de $O$ navio de Teseu. Também ao longo da narrativa, as posições críticas dos leitores de Straka -Caldeira, Eric e Jen- vão se reafirmar: as de Caldeira, postas no prefácio, ecoam nas notas de rodapé.

Olhando mais de perto o texto "Nota de tradução e prefácio", que se adequa à classificação de prefácio de Genette, é um prefácio alógrafo, pois não foi escrito pelo mesmo autor do livro, fictício; pois se trata de um autor imaginário, mesmo que possa se passar por real. Lembremos que o livro simula fielmente uma edição de 1949 e que não há nada nele, fora o box, que remeta a uma publicação atual. Assim, materialmente o livro leva o leitor a crer que Caldeira é um autor-criador real, quando é mais uma personagem desse quebra-cabeça literário ${ }^{14}$. 
A “falsificação" de uma publicação de 1949 é tão detalhadamente cuidada que até a segunda página, ou o verso da folha de rosto, que hoje comumente é ocupada pela ficha catalográfica, está completa em seu teor -ela contém a "declaração de ficcionalidade", o copyright, local e data de publicação e direitos de reprodução da obra ${ }^{15}$.

Quanto ao "contrato de ficcionalidade", diz Genette (2009, p. 192) que esta é "uma função reservada quase inevitavelmente para as obras de ficção, e sobretudo de ficção romanesca". 0 exemplo citado por Genette corresponde quase ipsis litteris ao que consta no livro de Straka:

As personagens e as situações desta narrativa são puramente fictícias e qualquer semelhança com pessoas ou situações existentes é mera coincidência. (Genette, 2009, p. 193, grifo no original)

Os personagens e acontecimentos deste livro são fictícios. Qualquer semelhança com pessoas reais, vivas ou mortas, é mera coincidência. (p. iv, grifo no original)

Aqui também a metaliterariedade está presente de maneira irônica, pois justamente a persecução do rastro de personagens e acontecimentos narrados de maneira alegórico-metafórica em $O$ navio de Teseu será o fio condutor da leitura paratextual da narrativa. Assim, ao inserir a anotação, mais do que apenas simular materialmente um livro de 1949, os autores inserem o objeto-livro na narrativa e o fazem ainda como um narrador não confiável -pois este livro vai se mostrar (através das narrativas secundárias) uma metáfora do que de fato aconteceu na realidade circunscrita a $S$. Explicando melhor: se aceitarmos o mundo narrativo criado em $S$, a narrativa $O$ navio de Teseu seria fictícia, mas os acontecimentos e personagens externos a ela (Jen, Eric, Caldeira) seriam reais. Neste universo, o livro se diz ficção, mas ele contém em termos metafóricos a narrativa do embate dois grupos políticos (o S. e o Novo S.) e a atuação de Straka como membro do S. original. Ou seja, mesmo os elementos paratextuais (que seriam um reflexo da realidade desse mundo e, portanto, "verdade") são falsos, pois não é coincidência que a realidade seja retratada no livro -é uma denúncia de Straka sobre a perseguição do Novo S. contra o S. original.

Os demais elementos da página, embora menos reveladores, também nos levam a buscar a falsa veracidade do livro. Importante perceber que o copyright pertence a Straka e Caldeira, provavelmente já um indício do peso que suas intervenções terão na narrativa -seja aquela contada em $O$ navio de Teseu, seja a paralela, a qual Jen e Eric perseguem. Além disso, há a menção a certas “Convenções Pan-Americanas de Copyright" sobre direitos autorais. Sendo mais comumente chamadas no Brasil de "Conferências Interamericanas", que ocorrem esporadicamente desde 1889, cuja última foi realizada em Havana, em 1928, e resultou na "Convenção Geral Interamericana de Proteção de Marcas de Fábricas e Proteção Comercial"16. Sendo Havana uma cidade importante para a narrativa externa à intriga principal, especialmente sobre a vida de Straka, manteremos essa informação em mente ${ }^{17}$.

Retomando, sobre a classificação de um prefácio alógrafo fictício, diz ainda Genette (2009, p. 168):

No prefácio alógrafo fictício (célula E), o prefaciador é fictício como o autor pretendido do texto, mas são duas pessoas distintas. Esse prefaciador fictício pode ser anônimo (mas provido de traços biográficos distintos) [...]. Mas esses casos são raros: em vez de inventar um prefaciador alógrafo, prefere-se geralmente conceder-lhe a identidade explícita conferida pelo nome.

Certamente Genette (2009, p. 20), cuja pesquisa, publicada originalmente em 1987, "não sai dos limites da cultura ocidental, e mesmo poucas vezes da literatura francesa" -e mesmo nesta, circula em um cânone expandido e pouco experimental-, não vislumbrava o uso produtivo dos elementos 
paratextuais como é feito em $S$. De qualquer forma, vemos que nosso tipo de prefácio pertence a uma tradição, em diálogo com a qual cria literariamente.

Além desta, outras características do prefácio postas por Genette (2009, p. 254, 234, 235, 239, 245,233 ) e aproveitadas em $S$. são "funções do prefácio denegativo: detalhes sobre a descoberta ou a transmissão do manuscrito [...], menção de eventuais correções [...], comentários morais [...]", além de "informar o leitor sobre as circunstâncias de sua vida [do autor]", "situar o texto apresentado no conjunto da obra de seu autor", usar a obra prefaciada como "simples pretexto para um manifesto, para uma confidência, para um acerto de contas, para uma divagação" ou ainda "para efetuar uma atribuição ficcional" ao texto prefaciado; e, "em caso de tradução, o prefácio pode ser, como acabamos de ver, assinado pelo tradutor. 0 tradutor-prefaciador pode eventualmente comentar (entre outras coisas) sua própria tradução". Importa ver que todas estas atribuições podem ser identificadas no prefácio de $O$ navio de Teseu -mesmo sabendo que estas não constituem a totalidade das atribuições possíveis a um prefácio. Sobretudo, elas podem ser ressignificadas a partir de sua função paratextual primeira para a construção de uma narrativa paralela ${ }^{18}$.

Neste momento, precisamos delimitar algumas questões. O livro, como já dito, foi concebido pelo cineasta J.J. Abrams. Ele é o criador de inúmeras séries de sucesso na TV americana, como Felicity (1998-2002), Lost (2004-2010) e Fringe (2008-2013), e diretor dos blockbusters: Missão Impossível: 3 (2006), dois filmes do universo Star Trek (Além da escuridão, 2013, e Sem fronteiras, 2016) e dois filmes do universo Star Wars (O despertar da força, 2015, e A ascensão de Skywalker, 2019). Estamos falando, portanto, de um autor que tem um excelente tino comercial e está imerso no mundo da cultura pop:

Os livros-objeto assimilam traços e/ou semelhanças de/com outras áreas como o cinema, a arquitetura, a publicidade, a embalagem e/ou com os objetos do dia a dia (como brinquedos), por exemplo, que, inevitavelmente, solicitam uma leitura distinta da tradicional e um novo perfil de leitor. (Martins e Silva, 2020, p. 101)

$\mathrm{Na}$ entrevista com Antônio Rhoden, designer que adaptou o conteúdo gráfico original para a versão brasileira, captamos a informação de que, embora a autoria do livro seja compartilhada entre Abrams e Doug Dorst, há uma equipe para a produção do volume ${ }^{19}$-como não poderia deixar de ser, dado o excesso de expertises que o autor da obra deveria dominar. Além da escrita, a arte gráfica de diversas formas é mobilizada para a produção dos sentidos almejados na publicação:

A aparência sedutora desses livros, prolíficos e heterogêneos, divide-se entre os livros crossovers que comungam de caraterísticas pós-modernas (como a fragmentação, a subversão, a descontinuidade ou a intertextualidade, a hibridez, por exemplo), e onde o designer (que, antes, solitário, acaba por trabalhar agora em equipe) coopera para reforçar a dimensão semântica, e os objetos lúdicos híbridos que incontestavelmente refletem a submissão do livro aos interesses mercantis. (Martins e Silva, 2020, p. 102)

Não estranha à discussão acadêmica acerca dessa obra seria, portanto, entender o lugar limítrofe em que ela se coloca: $S$. é um livro que requer um certo conhecimento do leitor quanto aos mecanismos de leitura e anotação marginal, bem como o refinamento da interpretação de texto; ao mesmo tempo, mantém uma dinâmica entre as narrativas própria dos atuais meios de comunicação para grandes públicos (TV, cinema, streaming), jogando com o interesse do leitor em todas as frentes narrativas que conduz concomitantemente.

Sobre isso, fala o filósofo alemão contemporâneo Christoph Turcke, quem, ao tratar da influência do cinema em nossas formas de percepção e expressão, diz que "cada corte de imagem atua como um golpe óptico que irradia para o espectador um 'alto lá, 'preste atenção, 'olhe para cá', e lhe aplica 
uma pequena nova injeção de atenção, uma descarga mínima de adrenalina -e, por isso, decompõe a atenção, ao estimulá-la o tempo todo" (Turcke, 2015, s/p.). Ou seja, o excesso de estímulos seria uma das variáveis contemporâneas que nos levaria à falta de atenção -ou a esta atenção que a todo momento precisa ser alimentada, estimulada ${ }^{20}$.

Então, quando dizemos que é possível, no livro $S$., rastrear visões teórico-críticas, não estamos dizendo que o livro nos oferece um tratado teórico-prático acerca da interação leitor/obra. 0 que é possível é traçar um caminho proposto de leitura ${ }^{21}$, em que apontamentos teóricos vão sendo inseridos nos discursos que emolduram $O$ navio de Teseu, de modo que as suas personagens-leitoras acabam discutindo as melhores formas de se relacionar com a narrativa -discursos nos quais é possível, portanto, identificar um posicionamento teórico. Não sendo, como apontado, o objetivo do livro a discussão teórica acerca da leitura, tais apontamentos podem ser demasiado superficiais para a academia, mas ainda apontam modos de leitura que visam atingir (educar?) as massas às quais a publicação parece ser mais direcionada.

Uma vez que a narrativa paratextual direciona para a persecução da identidade de V. M. Straka e de sua não concretizada relação amorosa com Filomela X. Caldeira, cujo escrutínio fica a cargo de Eric e Jen, toda a questão teórica está relacionada ao biografismo enquanto excessiva utilização de dados biográficos para a análise de obras literárias. A questão do biografismo na crítica literária, ou crítica biográfica, é uma corrente do pensamento sobre a literatura que ganhou força ao longo do século XIX e que, em meados do século passado, perdeu força para uma análise mais colada ao texto. A querela crítica pode ser dimensionada pelo teor do comentário de Afrânio Coutinho (1959, p. 67$)^{22}$ :

A biografia monopolizou quase por completo os estudos literários no Brasil, inclusive a crítica, a ponto de constituir um sério desvio a ser corrigido. Ela absorveu, por influência de Sainte Beuve ${ }^{23}$, a própria interpretação crítica, e chegou-se a inverter a ordem natural dos estudos literários: em vez de chegar-se à obra através do autor, como poderia ser o legítimo objetivo da biografia literária, passou-se a usar a obra como ponte para atingir-se o autor, idealizado romanticamente na sua individualidade. A hipertrofia biográfica chegou a ponto de afastar a leitura das obras em proveito do conhecimento da vida dos autores.

A reflexão de Coutinho reverbera na fala de Caldeira (1949, p. vi) no Prefácio de $O$ navio de Teseu: "De forma previsível, embora desapontadora, o mistério da identidade de Straka se tornou mais estudado que o conjunto de sua obra”.

Há outros momentos em que Caldeira reafirma a necessidade de que a crítica literária se atenha à Obra, e não ao Escritor (maiúsculas da prefaciadora): "Mas o foco no Escritor e não na Obra desonra ambos" (1949, p. vii). A reincidência desta consideração teórica poderia funcionar, não fosse o fato de a maior parte do prefácio se dedicar justamente à discussão das possíveis identidades de V. M. Straka, como pondera o jovem Eric em anotação à lápis no final do prefácio: "\{Por que acrescentar notas de rodapé que se concentram na questão da identidade se você acha que os leitores não deviam se importar? Não faz sentido!\}" (1949, p. xiv) ${ }^{24}$.

Existe, portanto, uma tensão entre posicionamentos teóricos acerca da importância da biografia do autor no interior do discurso de Caldeira. Contudo, o contexto em que se insere (o quebra-cabeça literário $S$.) expande a interpretação da postura da tradutora perante o texto: estamos diante de um meta-romance (sim, ao que parece, tudo nesse livro é "meta-"). Acompanhando as narrativas, veremos que há uma tentativa de comunicação entre autor e tradutora (Straka e Caldeira) através da escrita e publicação de $O$ navio de Teseu, código que vai sendo desvendado por Eric e Jen na narrativa secundária/marginal. Então, para entender camadas mais profundas da narrativa, é necessário 
recorrer ao biografismo -a um falso biografismo, veja bem, porque a única coisa que não é ficção em todo o volume é a sua existência material.

Assim, a persecução de Eric e Jen pela identidade e história de Straka e Caldeira é uma das narrativas que o leitor acompanha no livro, o que faz com que comentários biográficos levantados pela tradutora/prefaciadora acabem se imiscuindo à narrativa:

Não tenho qualquer anseio de identificá-lo, porque o conheci. Vi o mundo pelos olhos de seus personagens; ouvi sua voz nas cartas e em nossas discussões nas margens de seus originais; senti sua gratidão por meus esforços de levar suas histórias a um público mais amplo. (1949, p. x)

Embora nas primeiras páginas os leitores-personagens achem a postura crítica de Caldeira contraditória -como quando Eric comenta, sobre a citação acima: "\{Coisas assim mostram que FXC era um picareta\}" (1949, p. x)-, posteriormente, esse olhar biográfico é, de certa forma, assimilado à busca de Eric e Jen. Esse é o principal ponto de contato entre as narrativas -tanto para o desenvolvimento das intrigas secundárias (nos paratextos) quanto para uma perspectiva diferente à intriga principal ( $O$ navio de Teseu).

Mais frequente e mais evidentemente um pensamento crítico é a leitura antibiográfica proposta por Caldeira ${ }^{25}$. Entre o descrédito a interpretações "de limitado discernimento" e a evocação de estudiosos, destacamos a nota 13 do capítulo 7:

Alguns leitores talvez pensem: será isso talvez uma pista de como o Straka real podia parecer naquele momento da vida? A esses eu digo: leitores, vocês acham que um escritor do calibre de Straka é incapaz de imaginar o físico de um personagem? Precisam supor que um escritor pega emprestado de si mesmo todos os detalhes triviais de um personagem? (1949, p. 288)

De forma bastante incisiva e um pouco irônica, a tradutora destaca a capacidade imaginativa de um escritor, apontando uma superinterpretação biográfica por parte da crítica. Sobre a questão de extrapolar os limites do texto com a interpretação, já Eco (2015, p. xvii, grifo no original) alerta que o leitor pode "tentar uma grande variedade de significados e referentes... Mas não teria o direito de dizer que a mensagem pode significar qualquer coisa" ${ }^{26}$.

Já Straka, embora escreva uma narrativa metaliterária, não se debruça muito sobre o ato de ler, senão sobre o ato de contar histórias: "Escrever com a matéria negra é criar e, ao mesmo tempo, ressuscitar. Escrevemos com o que aqueles que vieram antes de nós escreveram” (1949, p. 451).

Entretanto, num dos documentos inseridos no meio da narrativa -uma carta sua a um cineasta que tentou adaptar sua obra para o cinema uma vez-, há algo no campo que estamos explorando nesta comunicação:

Nunca foi mais óbvio para mim que ninguém além do escritor pode entender o que é a sua história ou o que esta exige para ser narrada. ${ }^{27}$

Nesta passagem, é possível perceber a indiferença -ou até desprezo- do autor por uma interpretação do leitor que se afaste de sua intenção inicial. Certamente, o fato de que o referido leitor é um cineasta que fez um filme que, de acordo com Straka, corrompeu sua obra, auxilia nessa visão pouco aberta a interpretações. Mesmo assim, a situação específica transparece uma postura geral de Straka contrária à liberdade interpretativa. Essa postura do autor também pode estar relacionada ao teor de seus escritos: como escreve textos politizados, por causa dos quais corre inclusive risco de morte: 
Figura 7. recorte da página vi do Prefácio do livro. Destaca-se a leitura do trecho sublinhado e correspondente: comentário marcado com asterisco

\begin{tabular}{|c|c|}
\hline 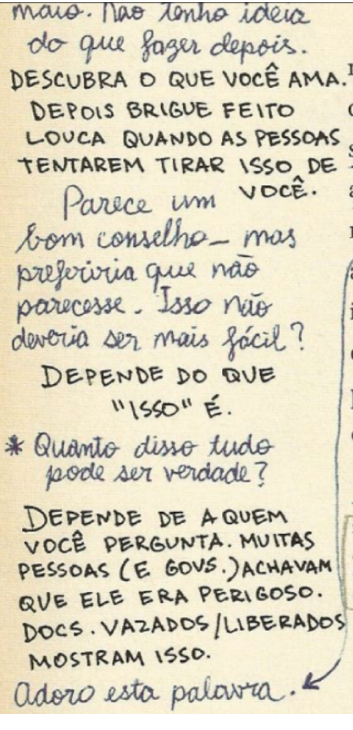 & 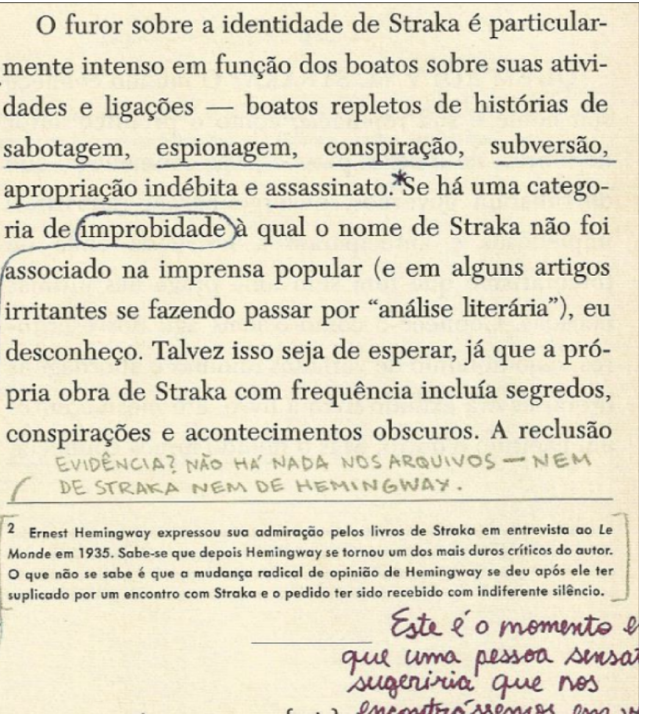 \\
\hline
\end{tabular}

Verossimilmente, os autores atribuem a Straka essa índole adversa à livre interpretação de sua obra, a qual reflete em como ele entende a função do seu leitor no contexto.

Na parte "tipográfica" da narrativa, seja ela os textos que simulam a publicação de 1949, há uma contundente conclamação ao antibiografismo que visa, de acordo com a narrativa secundária Straka-Caldeira, desviar a atenção do leitor presumido de $O$ navio de Teseu do seu fundo biográfico e da tentativa de comunicação de Caldeira com o autor. Essa situação gera uma tensão narrativa com a leitura biográfica que vai sendo "escavada" por Eric e Jen ao longo do volume. Essa atitude furtiva de Caldeira nas notas por vezes recorre a uma elaboração complexa, como quando ela evoca o discurso de autoridade como método argumentativo para que o leitor não siga por esta via (capítulo 6, nota 10):

Figura 8. detalhe da margem inferior da página 225 do livro

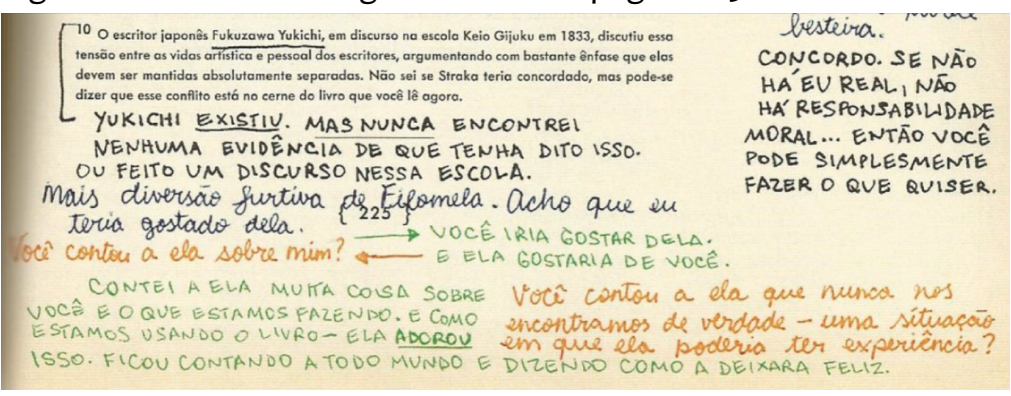

Caldeira (ou os autores de $S$.) poderia ter escolhido um teórico da literatura que de fato defendesse que a vida pessoal dos escritores não interfere na sua produção artística, mas ela (ou Abrams e Dorst) opta por uma informação deliberadamente falsa, tanto no mundo real quanto no universo da narrativa, como afirma Eric: "\{Yukichi existiu. Mas nunca encontrei nenhuma evidência de que tenha dito isso. Ou feito um discurso nessa escola\}" (1949, p. 225) ${ }^{28}$. Mais uma vez, vemos o paratexto atuando no cenário de apreciação da narrativa complexa que compõe $S$. 
Por outro lado, ao nos aproximarmos da intriga entre Jen-Eric, percebemos uma clara atitude pedagógica do pesquisador de doutorado perante a graduanda no que concerne à aproximação do leitor a uma obra literária.

Eric, e aos poucos Jen, empreende uma leitura acadêmica do texto de Straka, recorrendo a pesquisas de base documental e histórica para embasar sua leitura do romance. Suas anotações, especialmente aquelas feitas à lápis pelo jovem Eric e grande parte das anotações no prefácio e primeiro capítulo do livro tendem a uma postura cética principalmente perante as notas de Caldeira. Isso porque, como se vê na narrativa, as notas têm uma função que extrapola o seu uso comum, como apresentado acima. Mas essa leitura é feita “à margem”, ocupando um espaço chamado marginália:

O termo marginália, emprestado do latim, designa o conjunto das notas que os leitores introduzem nas margens e entrelinhas das páginas, no verso das capas ou nas folhas de guarda dos livros ou em periódicos sobre os quais se inclinam, anotações as quais, muitas vezes, se prolongam em folhas manuscritas, recortes de jornais ou revistas, postos no interior dos volumes. (Lopez, 2007, p. 33)

$\mathrm{Na}$ narrativa à margem, portanto, ocorre uma espécie de "educação científica" entre o doutorando Eric e a formanda Jen quanto à leitura e superinterpretação biográfica dos acontecimentos da narrativa (embora, ironicamente, a obra $O$ navio de Teseu seja altamente ligada às biografias de autor e tradutora). Especialmente no começo da obra, quando ainda não está clara a ligação da biografia com a narrativa, Eric tece alguns alertas:

Figura 9. recorte da página 17 do livro

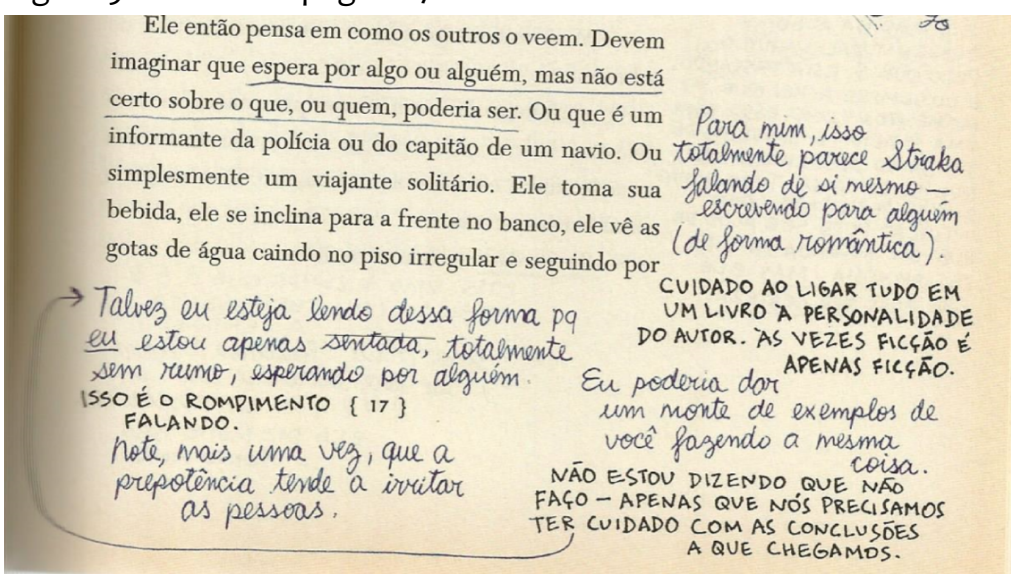


Figura 10. recorte da página 35 do livro

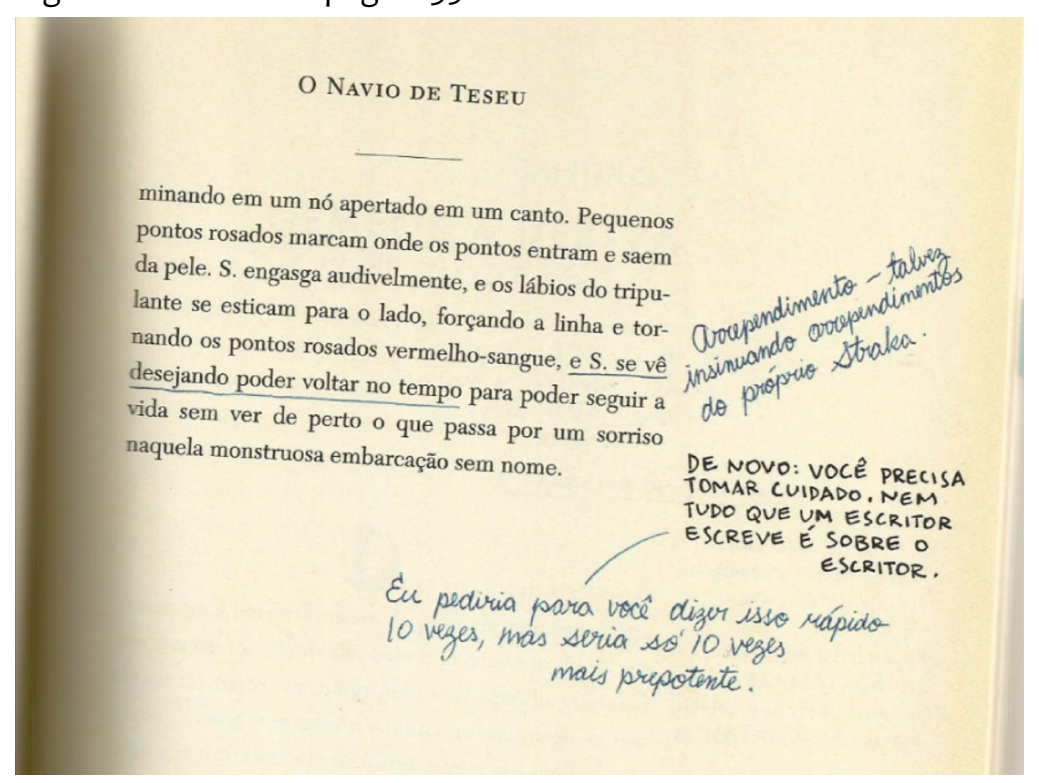

Mas a formação de Eric enquanto leitor nem sempre foi tão cética. Ele, na sua versão jovem, marcada à lápis nas anotações no livro, chega a questionar a afirmação de Caldeira, no prefácio, de que o foco deveria ser mantido na Obra, e não no Escritor (maiúsculas de Caldeira): “\{Por quê, quando a q. da identidade é essencial nos próprios livros? (Especialmente ONDT, SAPATOS ALADOS, CORIOLIS).\}" (p. vii).

Jen não recebe suas lições sem algum tipo de protesto, que pode ser percebido em duas posturas da personagem: em sua negação em ser uma "acadêmica" e na confirmação de que aquele livro pode ser lido num registro biográfico. Isto, perceba-se, não inviabiliza o pensamento de Eric acerca do biografismo, pois é algo a ser aplicado exclusivamente a este livro (e, com o decorrer da história, a esse autor).

No contexto do livro, "ser um acadêmico" diz da necessidade de legitimação de todas as suas assertivas acerca do livro através da interpretação e, principalmente, da busca de fontes, documentos e argumentos de autoridade que comprovem seu ponto de vista. Eric alerta Jen sobre isso algumas vezes, como em:

\{Jen: Não, não sabemos. Mas acho que é. [...] Não posso provar isso, mas como eu disse: não sou acadêmica.

Eric: Mas se está interessada em contar ao mundo a verdade sobre Straka, então tem que pelo menos fingir ser. Eu preciso tomar muito cuidado para o que digo ser verdadeiro, tenho que ser meticuloso sobre fontes etc. Se for descuidado, estou ferrado.\} (1949, p. 49)

A questão de uma possível superinterpretação também é tangencialmente abordada pela dupla de leitores, quando estão ponderando acerca da autoria dos livros que formam a obra de Straka. Assim, mesmo quando já aceitaram uma possibilidade de leitura biográfica da obra, ainda nesse momento é preciso ser cuidadoso quanto aos limites da interpretação possível à narrativa:

\{Eric: [...] Tipo nós queremos que seja verdade, então vemos o que queremos ver. [...]\} (1949, p. 234)

\{Jovem Eric: Vemos o que queremos ver. P. ex.: durandistas querem acreditar que VMS era uma mulher. Feuerbachers: que VMS era um anarquista terrorista, ekstromers: que VMS era o escritor que adoraram a vida toda. Vaclavistas: que VMS era uma história de fantasma que anda. MacInnesistas: que VMS era um grande intelectual. Etc. Etc. Etc.) (1949, p. 245) 
\{Jen: Mas não é engraçado acreditar na freira reencarnada-Straka? Torna o mundo um lugar mais interessante.

Ah, espere:

Você é um acadêmico.

A diversão não é permitida.\} (1949, p. 266)

A repetição da sentença "vemos o que queremos ver" (1949, p. 245) na caligrafia do jovem Eric e do Eric atual da narrativa marca uma manutenção na perspectiva acerca da leitura na personagem. Por mais que, no decorrer da trama, Eric abandone certo ceticismo academicista para perseguir a narrativa de Straka e Caldeira, sua concepção geral acerca da abordagem da obra literária continua a mesma.

Na última citação do bloco acima, faz-se notar a ironia mordaz de Jen quanto à postura crítica de Eric. Além de acrescentar sabor à narrativa, a citação também nos permite perceber o caminho do aprendizado de Jen que, mesmo tornando-se uma acadêmica, não perde o frescor da leitura apresentado desde o início da narrativa. Essas formulações individualizam o caráter de Jen, construindo-a enquanto personagem complexa na trama de $S$.

Por fim, Eric e Jen parecem alcançar um ponto de equilíbrio entre a crítica imoderada e o academicismo pedante, quando sintetizam a relação entre leitor e obra literária:

\{Jen: Imagine se você soubesse sobre o macaco na época?

Eric: Eu teria adorado. Não estou certo de que sei, ainda assim: é muito legal como as palavras podem permanecer as mesmas, mas seu significado pode mudar.

Jen: Porque o leitor muda.

Eric: Exatamente.\} (1949, p. 434)

O jogo de inversões se completa quando Eric admite que, no caso de $O$ navio de Teseu, não é possível desassociar a obra das vidas de Straka ou Caldeira: "\{Acho que agora eu entendi -é o jeito dela de enfatizar que o trabalho é deles, que estão criando juntos. E não apenas ONDT -estão criando juntos a história deles\}" (1949, p. 437). Esta anotação vem em resposta a uma das últimas notas de Caldeira no livro, que, circularmente, retoma informações que já haviam sido oferecidas no Prefácio:

Como mencionado no Prefácio, há várias páginas deste original que nunca foram localizadas em meio ao caos e ao sangue derramado em Havana. Eu escolhi não especificar onde as palavras de Straka e as minhas começam e terminam neste décimo capítulo reconstruído. Embora acadêmicos da literatura sem dúvida protestarão contra essa decisão, acredito que ela seja sólida; definir tais limites seria retratar a obra como um mero pastiche, em vez de uma colaboração que mantém a unidade das intenções de Straka em relação ao romance. (1949, p. 437, nota 8 , capítulo 10 )

Caldeira equilibra a questão da autoria de maneira bastante lúcida e criticamente embasada, uma vez que propõe uma "autoria compartilhada". Além do comentário apaziguado de Eric, a proposta de Caldeira abre espaço também para os voos interpretativos mais ousados de Jen.

Em suma, a narrativa $S$. é feita a partir de diferentes leituras e interpretações do texto, cada personagem ocupando seu espaço material dentro da publicação -o autor no texto, a tradutora/ prefaciadora nos paratextos e os leitores nas anotações à margem. Ao final, tem-se a narrativa de uma leitura que revela um estar no mundo de cada um de seus enunciadores e uma espécie produtiva de afronta ${ }^{29}$ que se concretiza na materialidade de $S$. No diálogo produtivo, problematizase os processos de leitura, crítica literária e pesquisa em estudos literários, ampliando suas possibilidades práticas e teóricas. 


\section{Referências}

\section{Bibliografia primária}

Abrams, J.J. e Dorst, D. (2015). S. Intrínseca.

Straka, V. M. (1949). O navio de Teseu. Editora Sapatos Alados.

Caldeira, F. X. (1949). Nota de tradução e prefácio. Em V. M. Straka, O navio de Teseu (pp. i-xvi). Editora Sapatos Alados.

\section{Bibliografia secundária}

Almeida, C. C., Nojima, V. L. S. (2018). A linguagem do design de S. - 0 navio de Teseu. Semeiosis: semiótica e transdisciplinaridade em revista, 8 (1), 1-23. http://www.semeiosis.com.br/a-linguagem-do-designde-s-\%E2\%80\%93-o-navio-de-teseu/

Araujo, R. C. (2010). De textos e de paratextos. Palimpsesto, 9 (10), 1-5. https://www.e-publicacoes.uerj.br /index.php/palimpsesto/article/view/35183

Bakhtin, M. (2014). 0 problema do conteúdo, do material e da forma na criação literária. Em M. Bakhtin, Questões de literatura e de estética: a teoria do romance (pp.13-70) [7 ed.]. Hucitec.

Bakhtin, M. (2017). Fragmentos dos anos 1970-1971. Em M. Bakhtin, Notas sobre literatura, cultura e ciências humanas (pp. 21-56). Editora 34.

Borges, J. L. (2009). Prólogos, com um prólogo de prólogos. Companhia das Letras.

Coutinho, A. (1959). Introdução à literatura no Brasil. Livraria São José.

Eco, U. (2015). Os limites da interpretação. Perspectiva.

Frankel, R. D. (2014). Quando não utilizar dados biográficos na análise literária: uma discussão baseada na analítica existencial de Martin Heidegger e no romance $O$ lobo da estepe de Hermann Hesse. Criação $e$ Crítica, 12, 53-65. https://doi.org/10.11606/issn.1984-1124.v0i12p53-65

Genette, G. (2006). Palimpsestos: a literatura de segunda mão. Faculdade de Letras.

Genette, G. (2009). Paratextos editoriais. Ateliê Editorial.

Helene, A. F. e Xavier, G. F. (2003). A construção da atenção a partir da memória. Rev. Bras. Psiquiatr., 25 (2), 12-20. https://doi.org/10.1590/S1516-44462003000600004

Idris, L. (2016) S. Prelúdios. http://leonidris.blogspot.com/2016/02/s.html

Intrínseca (2015). O quebra-cabeça literário de J.J. Abrams. https://www.intrinseca.com.br/blog/2015/11/ o-quebra-cabeca-literario-de-j-j-abrams/

Livraria da Folha (6 de janeiro de 2016). J.J. Abrams lança quebra-cabeça literário com várias possibilidades de leitura. Folha de S. Paulo. http://www.folha.com/no1726487

Lopez, T. A. (2007). A criação literária na biblioteca do escritor. Cienc. Cult., 59 (1), 33-37. https://www.sh orturl.at/dmqG9

Maia, F. (2019). 0 corpo sensível do livro-objeto. Revista Continente, 221. https://revistacontinente.com.br /edicoes/221/o-corpo-sensivel-do-livro-objeto

Marín, D. (1958). La intriga secundaria en el teatro de Lope de Vega. University of Toronto Press.

Martins, D. M. e Silva, S. R. (2020). A evolução do livro-objeto: técnica e estética. Fronteiraz, 24, 87-103. htt ps://doi.org/10.23925/1983-4373.2020i24p87-103

Pavis, P. (2008). Dicionário de teatro. Perspectiva. 
Textos-moldura como literatura: o meta-paratexto de um quebracabeça literário

Pereira, G. L. (2020). Durante muito tempo fomos dormir cedo: Proust, Barthes e Mário Cláudio contra SainteBeuve. Desassossego, 12 (23), 185-202. https://doi.org/10.11606/issn.2175-3180.v12i23p185-202

Porto Editora (s./d.). Paratexto: aprender para saber. http://www.shorturl.at/prN15

Quindim (2020). Livro-objeto: entenda o que é e como a forma pode transformar a leitura. https://quindim .com.br/blog/livro-objeto/

Rita, A. (2010) Mise en abyme (mise en abîme). E-dicionário de termos literários de Carlos Ceia. https://edt l.fcsh.unl.pt/encyclopedia/mise-en-abyme/

Rothman, J. (23 de novembro de 2013). The Story of "S": Talking With J.J. Abrams and Doug Dorst. The New Yorker. https://www.newyorker.com/books/page-turner/the-story-of-s-talking-with-j-j-abrams-and -doug-dorst

Turcke, C. (2015). Cultura do déficit de atenção. Serrote (Instituto Moreira Salles), 19. https://revistaserrot e.com.br/2015/06/cultura-do-deficit-de-atencao/

Notas

1 Ao longo do texto há diversas imagens que exemplificam e permitem parte da experiência da leitura de $S$.

2 Tradução da Livraria da Folha (2016). No original: "It's intended to be a celebration of the analog, of the physical object. In this moment of e-mails, and texting, and everything moving into the cloud, in an intangible way, it's intentionally tangible. We wanted to include things you can actually hold in your hand: postcards, Xeroxes, legal-pad pages, pages from the school newspaper, a map on a napkin".

3 Patrice Pavis (2008, p. 245) define o mise en abyme como o "procedimento que consiste em incluir na obra (pictórica, literária ou teatral) um enclave que reproduz certas propriedades ou similitudes estruturais dela".

4 Descobre-se logo no início da narrativa (p. 29) que Francisco Xabregas Caldeira é, na verdade, Filomela Xabregas Caldeira: "Eric!! -eu localizei as listas de passageiros de todos os navios que chegaram a NY vindos do Brasil entre 1923/1929. Não há nenhum Francisco Felipe Xabregas Caldeira... MAS: Houve uma Filomela Xabregas Caldeira que apareceu com frequência na tripulação do Imperia -como tradutora. E em 15/5/24 havia um passageiro no Imperia chamado S.Opice-Tance [suposto codinome de V. M. Straka]".

5 O livro-objeto que constitui S. é a simulação perfeita de um livro publicado em 1949 -que seguramente seria confundido com um livro antigo autêntico sem o box em que é comercializado. Assim, pela dificuldade de referenciar a obra, entre texto, notas e anotações à margem, optamos por indicar apenas as páginas em que os excertos citados se encontram.

6 Tradução nossa. No original: "más goce estético en llegar a la unidad y al orden a través de la multiplicidad y del aparente desorden que por medio de la simplicidad y claridad de las obras clásicas".

7 "Essas observações sobre a força ilocutória conduziram-nos, portanto, sem perceber, para o essencial, que é o aspecto funcional do paratexto. Essencial, porque, ao que tudo indica e salvo exceções pontuais que encontramos aqui e ali, o paratexto, sob todas as suas formas, é um discurso fundamentalmente heterônomo, auxiliar, a serviço de outra coisa que constitui sua razão de ser: o texto. Qualquer que seja o investimento estético ou ideológico ('belo título', prefácio-manifesto), coquetismo ou inversão paradoxal que o autor coloque nele, um elemento de paratexto está sempre subordinado a 'seu' texto, e essa funcionalidade determina o essencial de sua conduta e de sua existência" (Genette, 2009, p. 17-18).

8 Marín (1958, p. 158) afirma que a ligação das intrigas é mecânica quando "la suerte de dicha intriga subordinada va ligada a la de la principal”.

9 Embora a maior parte das anotações à margem do capítulo 10 de $O$ navio de Teseu tenham sido feitas com a mesma tinta de caneta, independente se escritas com a letra de Jen ou Eric, identificamos, ao todo, cinco intercorrências 
explícitas da presença de ambos no mesmo espaço (p. 419, 421, 432, 447 e 454), pois também consideramos o conteúdo do que as personagens escrevem.

10 O protagonista de $O$ navio de Teseu também é chamado apenas de "S.". Assim, S. pode ser este protagonista, O grupo ao qual pertence Straka, o grupo oposto ao de Straka (que Jen e Eric acabam por chamar de Novo S., para não se confundirem), além do próprio título do quebra-cabeça literário. Como não nos interessa grandemente neste artigo a questão do entrecruzamento de narrativas, deixaremos maiores detalhes para o sabor da leitura do livro.

11 Será utilizado o sinal gráfico \{\} para marcar as citações de anotações à margem do texto publicado O navio de Teseu, cuja voz será sempre apresentada no corpo da citação.

12 "Eötvös é a roda encartada na última guarda do livro. Ela é feita em duas lâminas de papel [...] fixada com um ilhóes no centro que permite girá-la. Ela tem um vazado no qual se visualizam letras desvendadas por meio de um enigma proposto no capítulo 10" (Almeida e Nojima, 2018, p. 17).

13 Perceba que não estamos sugerindo que prefácios tradicionais sejam supérfluos ou desnecessários. Sobre esta questão, Genette (2009, p. 15, grifo nosso) relembra, como exemplo, dos paratextos a Em busca do tempo perdido [La recherche du temps perdu], de Marcel Proust: "para a maioria dos leitores da Recherche, o conhecimento de dois fatos biográficos, a semiascendência judaica de Proust e a sua homossexualidade, inevitavelmente forma paratexto nas páginas de sua obra dedicadas a esses dois temas. Não digo que seja necessário saber disso: digo apenas que aqueles que sabem não leem da mesma forma que aqueles que não sabem, e que aqueles que negam essa diferença estão zombando de nós".

14 "Para efetuar uma ficção, todos os romancistas sabem disso, é preciso um pouco mais do que uma declaração peremptória; é preciso constituir essa ficção, com muitos detalhes ficcionalmente convincentes; é preciso, pois, enriquecê-la e, para tanto, o meio mais eficaz parece ser simular um prefácio sério, com todo o aparato de discursos, de mensagens, isto é, de funções que isso comporta" (Genette, 2009, p. 245, grifos no original).

15 Poderíamos chamar a atenção para as marcas de carimbo de "Livro para empréstimo" na guarda ou "Propriedade da biblioteca do Colégio Laguna Verde" na folha de rosto. Se chamamos a atenção para o verso da folha de rosto, é porque ele também dialoga com nosso objetivo neste artigo, seja ele a discussão da crítica literária presente nos paratextos de O navio de Teseu.

16 Informações acerca de propriedade intelectual obtidas no site https://jus.com.br/artigos/5806/nocoes-de-direito-a utoral-e-sua-regulamentacao-internacional (consulta: 4 abril, 2021). Este texto, por sua vez, recorre a Eduardo Pimenta, Dos crimes contra a propriedade intelectual (1994), São Paulo: Ed. RT; e Carlos Alberto Bittar, Direito de Autor (2003), Rio de Janeiro: Forense Universitária.

17 Posteriormente, em 1946, foi firmada em Washington (EUA) a "Convenção Internacional de Direitos do Autor em obras literárias, científicas e artísticas". Sendo O navio de Teseu publicado em 1949, cuja sede da editora fica em Nova York, a publicação deveria estar sob essa jurisdição. Entretanto, seja para maior sabor da narrativa, seja pela maior aproximação onomástica, manteremos como principal a informação apresentada no corpo do artigo.

18 "Outros [prefácios] podem, no todo ou em parte, valer-se do modo narrativo, por exemplo, para fazer o relato, verídico ou não, das circunstâncias da redação [...] ou da descoberta do texto, quando é atribuído a um autor fictício [...], e é, na verdade, raríssimo que um prefácio não contenha aqui ou ali tais fundamentos narrativos" (Genette, 2009, p. 153).

19 Almeida e Nojima (2018, p. 2) nos informam que o livro foi "projetado pelo designer Paul Kepple". Paul Kepple é dono da Headcase Design e professor na Tyler School of Art da Temple University (Filadélfia, Pensilvânia, EUA).

20 A atuação da imagem fílmica (cinema, TV etc.) na atenção pode ser equiparada (ou se tornam, ou forçam) os processos automáticos de captação da atenção. Como descrevem Helene e Xavier (2003, p. 16, grifo nosso): "Admitese que processos automáticos de captação da atenção sejam velozes e não requeiram 'controle ativo' por parte da pessoa [...]; além disso, eles podem ser desencadeados prontamente, de forma quase inevitável, por eventos inesperados, surpreendentes ou incongruentes no ambiente, mesmo que o participante não esteja, inicialmente, prestando atenção à fonte da estimulação". Tais eventos seriam os "golpes ópticos" de Turcke. Pelo contrário, os "processos voluntários de 
direcionamento da atenção demandam recursos de processamento [...]. Além disso, o controle voluntário da atenção apresenta um componente consciente para sua realização e é, geralmente, usado para tarefas mais complexas ou não familiares, requerendo assim mais tempo para a execução" (Helene e Xavier, 2003, p. 16, grifo nosso), tempo que não é aprendido pela interferência da tela na vida do indivíduo, de acordo com o raciocínio de Turcke (2015, s/p.), "já que a tela pertence tanto ao computador como à televisão, ela não só preenche o tempo livre, mas atravessa a vida toda, também durante o tempo de trabalho".

21 “[...] por trás dessa simulação [do paratexto] ficcional, nada impede ao autor (real) do prefácio de dizer ou fazer dizer, a respeito do texto do qual também é o autor real, várias coisas que pensa seriamente" (Genette, 2009, p. 246).

22 Na contemporaneidade, "o retorno do autor é marcado pelo retorno não de um sujeito 'pleno, fundamento e autoridade transcendente do texto', mas sim de um sujeito 'não essencial, fragmentado, incompleto e suscetível de autocriação' (Kingler, [Escritas de si, escritas do outro: o retorno do autor e a virada etnográfica], 2012, p. 57)" (Frankel, 2014, p. 55).

23 Charles Augustin Sainte-Beuve acreditava que era possível que fosse feita uma crítica isenta da obra literária, tendo por base a biografia do autor. Seu nome é tão fortemente ligado a esta corrente de pensamento que já teve seus escritos rechaçados por Roland Barthes e Marcel Proust. Em artigo recente Pereira (2020) inclusive utiliza o nome de Saint-Beuve como metonímia do método crítico.

24 "O que um elemento de paratexto levanta, um outro elemento de paratexto, posterior ou simultâneo, pode sempre tirar, e aqui como alhures, o leitor deve compor o conjunto e tentar (o que não é sempre simples) explicitar-lhe a resultante. E a própria maneira pela qual um elemento de paratexto coloca o que coloca pode sempre dar a entender que nada daquilo é crível" (Genette, 2009, p. 163). Parece que os autores de S. estiveram o tempo todo jogando com as indicações de Genette quanto aos paratextos literários.

25 “Tenho pouco interesse em argumentar qual 'candidato' -plausível, fantástico ou outro- a Straka é o mais forte. [...] Eu me interesso pela qualidade artística de suas obras e a paixão de suas convicções” (p. ix-x).

26 Ainda o mesmo Eco (2015, p. xvii) continua: "Pode significar muitas coisas, mas sentidos há que seria arriscado sugerir. [...] contestar leitura tão desviante também pode ser um ponto de partida razoável para concluirmos que pelo menos alguma existe que a mensagem efetivamente não pode dizer".

27 Carta de Straka ao Sr. Grahn, Arquivo Straka de Uppsala, Uppsala Universitet. Inserida no meio do livro O navio de Teseu por Eric.

28 Tampouco nós encontramos referência à discussão na obra de Yukichi, embora não tenhamos realizado pesquisa exaustiva a respeito. Acreditamos, contudo, que a instituição se refira à Universidade Keio [Keiō Gijuku Daigaku], fundada em 1858 por Fukuzawa Yukichi.

29 "A interpretação criadora continua a criação, multiplica a riqueza artística da humanidade. [...] No ato da compreensão desenvolve-se uma luta cujo resultado é a mudança mútua e o enriquecimento" (Bakhtin, 2017, p. 36). 